\title{
Victimisation of hunger strikers at Guantánamo Bay
}

\author{
Katie Taylor, MA*
}

In recent weeks, Reprieve ${ }^{1}$ has gathered reports from those we assist in detention in Guantánamo Bay. They show that under the Trump Administration, the authorities at the prison have begun cracking down harder than ever on those who are hunger striking. Medical assistance is being used as a tool of coercion, with prisoners on hunger strike being denied essential checks on their blood and vital signs. Force feeding-once carried out with brutal regularity-is now undertaken at the point where prisoners are near collapse, meaning that hunger strikers face a real risk of permanent injury. At least 780 detainees have been held at Guantanamo since the prison there opened in 2002. Today, 41 detainees remain at the prison, in conditions of indefinite detention which compound their existing trauma. Several of these men have undertaken a hunger strike, as their only means of peacefully protesting their detention without charge or trial.

Guantanamo detainees have been hunger-striking at the prison for years; and for many years, the authorities has been force feeding the prisoners. While the prison authorities have claimed that this is a necessary medical measure, designed to ensure basic

\footnotetext{
*) Reprieve, London

1 To find out more visit www.reprieve.org.uk/topic/
} guantanamo-bay/ nutrition for the detainees, evidence gathered by Reprieve has shown that in practice, force feeding is part of a brutal regime designed to punish the hunger strikers. Prisoners have been routinely subjected to 'forced cell extractions' or FCEs, during which they are stormed in their cells by guards clad in riot gear, beaten, and then dragged to the feeding chair. The tubes used to force feed prisoners are regularly used at the wrong size, causing agonising pain as they were inserted into the stomach through the nose. In 2014, the UN Committee Against Torture warned the Obama Administration that the force feeding of prisoners on hunger strike, even without such additional abuse, constituted "ill-treatment in violation of the Convention [Against Torture]."

Khalid Qasim is a Yemeni national who has been held without charge or trial since 2002. He told Reprieve that his requests to see a doctor, and to have his vital signs checked, had been repeatedly refused since September. He is no longer allowed to take vitamins. He has repeatedly collapsed in recent weeks, and feels weak and dizzy. His joints are beginning to ache. He says he is terrified that he could die, or suffer permanent organ damage. This is why Reprieve is calling on the Trump administration to allow the prisoners urgent independent medical attention - and to listen to their protest. Ultimately, the prisoners must be 
given fair trials, or released, and the prison closed for good.

Prisoners who are not hunger striking, such as Saifullah Paracha, have also been victimised. Saifullah - a grandfather from Pakistan who has never been charged-recently told his lawyer at Reprieve that he had just been 'FCEed' for the first time. He said: "It felt like when we were brought in to Gitmo. Not since the beginning days of Guantanamo has it been like this. It's a hell." He described the abuse as "collective punishment", handed down "because of the hunger strike."

In the last issue of the Torture Journal, I and a former colleague at Reprieve, Polly Rossdale, wrote in these pages about the torture suffered by prisoners at Guantánamo Bay, and the sequelae of that torture. Our article highlighted the fact that the majority of men held in Guantanamo were indefinitely detained without charge or trial, and were subjected to rendition, torture and other cruel, inhuman and degrading treatment. For those released, the consequences of that torture has a daily impact on their ability to rebuild their lives. 